\title{
KEMAMPUAN MENULIS CERPEN DENGAN PERLAKUAN MODEL PENGAJARAN TIDAK LANGSUNG DAN MODEL KOOPERATIF INTEGRATIF PADA SISWA SMA DILIHAT DARI TINGKAT KEMANDIRIAN SISWA
}

\author{
Mila Roysa \\ milaroysa87@gmail.com \\ Universitas Muria Kudus
}

\begin{abstract}
ABSTRAK
Kemampuan menulis cerpen siswa kelas $\mathrm{X}$ rendah. Rendahnya kemampuan menulis cerpen disebabkan oleh beberapa hal, antara lain kurangnya minat siswa terhadap pembelajaran menulis cerpen, guru belum melaksanakan penerapan model pembelajaran yang inovatif ketika proses pembelajaran berlangsung, dan guru kurang dalam melaksanakan pembelajaran kurang memperhatikan karakter karakter peserta didik.

Masalah yang diteliti adalah (1) apakah berbeda secara signifikan kemampuan menulis cerpen siswa yang memiliki tingkat kemandirian tinggi setelah mengikuti pembelajaran dengan perlakuan model pengajaran tidak langsung dan model kooperatif integratif dan (2) apakah berbeda secara signifikan kemampuan menulis cerpen siswa yang memiliki tingkat kemandirian rendah setelah mengikuti pembelajaran dengan perlakuan model pengajaran tidak langsung dan model kooperatif integratif.

Tujuan penelitian ini adalah (1) menentukan perbedaan kemampuan menulis cerpen siswa yang memiliki tingkat kemandirian tinggi setelah mengikuti pembelajaran dengan perlakuan model pengajaran tidak langsung dan model kooperatif integratif dan (2) menentukan perbedaan kemampuan menulis cerpen siswa yang memiliki tingkat kemandirian rendah setelah mengikuti pembelajaran dengan perlakuan model pengajaran tidak langsung dan model kooperatif integratif.

Penelitian ini termasuk jenis eksperimen quasi. Hasil penelitian ini adalah bahwa (1) model pengajaran tidak langsung cocok untuk pembelajaran kemampuan menulis cerpen dilihat dari siswa yang memiliki tingkat kemandirian tinggi dan (2) model kooperatif integratif cocok untuk pembelajaran kemampuan menulis cerpen dilihat dari siswa yang memiliki tingkat kemandirian rendah dan ada interaksi antara model pengajaran tidak langsung dan model kooperatif integratif.

Simpulan hasil penelitian ini adalah (1) model pengajaran tidak langsung cocok untuk pembelajaran kemampuan menulis cerpen dilihat dari siswa yang tingkat kemandirian tinggi dan (2) model kooperatif integratif cocok untuk pembelajaran menulis cerpen dilihat dari siswa yang memiliki tingkat kemandirian rendah.
\end{abstract}

Kata Kunci: model pengajaran tidak langsung dan model kooperatif integratif, tingkat kemandirian siswa, kemampuan menulis cerpen.

\footnotetext{
ABSTRACT

The Ability to Write Short Stories with NonDirected Teaching Model and Integrative Cooperative Model to Senior High School Students from the Level of Students Independence.
} 
The ability to write short stories class $\mathrm{X}$ is less satisfactory. The low ability to write short stories is caused by several reasons for example lack of interest of students towards learning to write short stories, students think that writing is difficult, it requires hard skills, lack of concentration and time, so the students feel bored, and the result is still unsatisfactory, the students often make the mistake relates to the cohesion elements of short stories, it happened because it has not been applied innovative learning model by teachers in the learning process. Therefore, we need effective learning model in order to facilitate students to practice writing short stories. The learning model chosen in this thesis are nondirected teaching model and integrative cooperative model.

There are three problems in this research, they are: (1) is there any difference in the ability to write short stories of students who have high level of independence after following treatment of learning with nondirected teaching model and integrative cooperative model? (2) is there any difference in ability to write short stories of students who have low level of independence after following treatment of learning with nondirected teaching model and integrative cooperative model?

The objectives of this research are (1)to know the differences in the ability to write short stories of students who have high level of independence after following learning model with the treatment of nondirected teaching model and integrative cooperative model, (2) to know the differences in the ability to write short stories of students who have low level of independence after following learning model with the treatment of nondirected teaching model and integrative cooperative model

The design of this research is quasi experimenta. Class X-2 as an experimental class of integrative cooperative model and class $\mathrm{X}-3$ as an experiment class of nondirective teaching model. The variables in this research are the type of learning model, the level of independence, and ability to write short stories. The data obtained were processed by descriptive analysis and the different test variants.

The results of the research shows that (1) nondirective teaching model is appropriate for learning ability to write short stories for the students who have high level of independence. (2) integrative cooperative model is appropriate for learning ability to write short stories for students who have low level of independence and there is an interaction between nondirective teaching model and integrative cooperative model.

The conclusions of this research are (1) nondirective teaching model is appropriate for learning ability to write short stories for the students who have high level of independence. (2) integrative cooperative model is appropriate for learning ability to write short stories for students who have low level of independence and there is an interaction between nondirective teaching model and integrative cooperative model. The writer has some suggestions as follows. Teachers can use Not directed teaching model to improve the ability of students who have high degree of independence because nondirected teaching model is one of the innovative learning model that can facilitate students to share ideas and build a good communication. This model can create an environment that allows students and teachers work together in the learning process, especially the ability to write short stories. Teachers can use integrative cooperative model to improve the ability of students who have low level of independence because integrative cooperative model is one of the innovative learning model that can motivate students because they work in groups in order to improve student learning outcomes and can help students who are low in the ability to write short stories and 
always do the innovation of learning with the appropriate learning models to the conditions of students in order to create an active, innovation, creative, and fun.

Keywords: nondirective teaching model and integrative cooperative model, the level of student independence, the ability to write short stories.

\section{PENDAHULUAN}

Salah satu keterampilan berbahasa yang harus dikuasai peserta didik dalam mata pelajaran bahasa Indonesia di SMA adalah menulis. Keterampilan berbahasa ini merupakan keterampilan pada tingkatan paling tinggi sehingga membutuhkan kemampuan dan ketekunan.Rendahnya kemampuan menulis cerpen siswa disebabkan oleh beberapa hal antara lain kurangnya minat siswa terhadap pembelajaran menulis cerpen, guru belum melaksanakan penerapan model pembelajaran yang inovatif ketika proses pembelajaran berlangsung, dan guru kurang dalam melaksanakan pembelajaran kurang memperhatikan karakter karakter peserta didik. Oleh karena itu, dibutuhkan suatu modelpembelajaran yang efektif agar mempermudah siswa dalam mempraktikan menulis cerpen dan guru harus memperhatikan karakter peserta didik. Model pembelajaran yang dipilih adalah model pengajaran tidak langsung dan model kooperatif integratif.

Model pengajaran tidak langsung menciptakan sebuah lingkungan yang memudahkan siswa dan guru bekerja sama dalam proses pembelajaran. Ketika menerapkan model ini, guru harus berusaha melihat dunia yang ada dalam pikiran siswa, menciptakan atmosfer komunikasi yang sarat dengan empati sehingga arah dan pendirian pribadi siswa dapat dibimbing dan dikembangkan. Peran tidak langsung menyajikan beberapa masalah yang menarik. Pertama, adanya pembagian tanggung jawab. Pada model ini, kejadian-kejadian yang membentuk dan melukiskan berbagai macam aktivitas muncul dengan sendirinya dan pola aktivitas-aktivitas akan selalu berubah-ubah. Kedua, konseling dalam model tidak langsung dapat menciptakan serangkaian respons yang terjadi dalam rangkaian yang tidak terduga (Carl Rogers 1961,1971).

Model kooperatif integratif merupakan model pembelajaran yang menggabungkan proses belajar membaca dan menulis. Slavin (2010:200) mengemukakan bahwa pembelajaran dilaksanakan secara terpadu sehingga keterampilan membaca dan menulis dapat berkembang secara seimbang. Dengan demikian, keterampilan menulis juga akan mengalami perkembangan seiring dengan intensitas kegiatan membaca yang dilaksanakan.

Model pengajaran tidak langsung dan model kooperatif integratif sebagai alternatif untuk membelajarkan menulis cerpen kepada siswa akan dapat menolong siswa mengembangkan kualitas menulisnya, karena kedua model tersebut memiliki keunggulan. Salah satu keunggulan model pengajaran tidak langsung yaitu memudahkan siswa untuk saling berbagi gagasan secara terbuka dan membangun komunikasi yang sehat, sedangkan salah satu keunggulan model kooperatif integratif adalah siswa termotivasi pada hasil secara teliti, karena bekerja dalam kelompok.

Berdasarkan uraian di atas, maka peneliti tertarik untuk melakukan penelitian tentang "Kemampuan Menulis Cerpen dengan Perlakuan Model Pengajaran Tidak Langsung dan ModelKooperatif Integratifpada Siswa SMA dilihat dari Tingkat Kemandirian Siswa".

\section{Rumusan Masalah}

Berdasarkan latar belakang masalah dan rumusan masalah penelitian ini sebagai berikut.

(1) Apakah berbeda secara signifikan kemampuan menulis cerpen siswa yang memiliki tingkat kemandirian tinggi setelah mengikuti pembelajaran dengan perlakuan model 
pengajaran tidak langsung dan model kooperatif integratif?

(2) Apakah berbeda secara signifikan kemampuan menulis cerpen siswa yang memiliki tingkat kemandirian rendah setelah mengikuti pembelajaran dengan perlakuan model pengajaran tidak langsung dan model kooperatif integratif?

\section{Tujuan Penelitian}

Sesuai dengan latar belakang masalah, identifikasi masalah, rumusan masalah, serta cakupannya, tujuan penelitian ini adalah sebagai berikut:

(1) menentukan perbedaan kemampuan menulis cerpen siswa yang memiliki tingkat kemandirian tinggi setelah mengikuti pembelajaran dengan perlakuan model pengajaran tidak langsung dan model kooperatif integratif.

(2) menentukan perbedaan kemampuan menulis cerpen siswa yang memiliki tingkat kemandirian rendah setelah mengikuti pembelajaran dengan perlakuan model pengajaran tidak langsung dan model kooperatif integratif.

\section{KERANGKA TEORETIS}

Kerangka teoretis dalam penelitian ini mencakup banyak hal antara lain, hakikat cerpen, unsur pembangun cerpen, proses kreatif menulis cerpen, kiat menulis cerpen, langkah pembelajaran menulis cerpen, model pembelajaran kooperatif, pembelajaran kooperatif integratif, model pengajaran pribadi (personal), model pengajaran tidak langsung, kemandirian belajar.

\section{Unsur Pembangun Cerita Pendek}

Cerpen tersusun atas unsur-unsur pembangun cerita yang saling berkaitan erat antara satu dengan yang lainnya. Keterkaitan unsur-unsur pembangun tersebut membentuk totalitas yang abstrak. Koherensi dan kepaduan semua unsur cerpen yang membentuk sebuah totalitas amat menentukan keindahan dan keberhasilan cerpen sebagai suatu cipta sastra. Unsur-unsur tersebut terdiri atas tema, alur (plot), tokoh dan penokohan, latar (setting), sudut pandang (point of view), gaya bahasa (style), dan amanat (Sayuti 1988:3).

\section{Model Pengajaran Tidak Langsung}

Model pengajaran tidak langsung, merupakan bagian dari model personal. Model personal berpijak dari pandangan individu (selfhood). Proses mendidik sengaja dilaksanakan untuk memungkinkan dapat memahami diri sendiri dengan baik, memikul tanggung jawab, dan lebih kreatif untuk mencapai kualitas hidup yang lebih baik. Kelompok model personal memusatkan perhatian pada pandangan perseorangan dan berusaha menggalakkan kemandirian yang produktif sehingga manusia menjadi semakin sadar diri dan bertanggung jawab atas tujuannya. Model yang termasuk dalam kelompok model personal adalah (1) pengajaran nondirektif; (2) latihan kesadaran (atwareness training); (3) synectics; (4) sistem konsepsional; (5) pengajaran tidak langsung; dan (6) pertemuan kelas (Joyce dan Weil 2009:373).

\section{Model Kooperatif Integratif}

Model pembelajaran kooperatif merujuk pada berbagai macam model pengajaran dan siswa bekerja dalam kelompok-kelompok kecil untuk saling membantu satu sama lainnya dalam mempelajari materi pelajaran. Dalam kelas kooperatif, para siswa diharapkan dapat saling membantu, mendiskusikan dan berargumentasi, untuk mengasah pengetahuan yang mereka kuasai saat itu dan menutup kesenjangan dalam pemahaman masing-masing. Cara 
belajar kooperatif jarang sekali menggantikan pengajaran yang diberikan oleh guru, tetapi lebih seringnya menggantikan penaturan tempat duduk yang individual, cara belajar individual, dan dorongan yang individual. Apabila diatur dengan baik, siswa-siswa dalam kelompok kooperatif akan belajar satu sama lain untuk memastikan bahwa setiap orang dalam kelompok telah menguasai konsep-konsep yang telah dipikirkan (Slavin 2008:4).

Tujuan utama dari pembelajaran kooperatif pembelajaran integratif adalah menggunakan tim-tim kooperatif untuk membantu para siswa mempelajari kemampuan memahami bacaan yang dapat diaplikasikan secara luas. Pembelajaran kooperatif integratif merupakan model pembelajaran yang menggabungkan proses belajar membaca dan menulis. Beberapa unsur pembelajaran kooperatif integratif memang diarahkan untuk tujuan ini. Selama masa tindak lanjut, para siswa bekerja berpasangan untuk mengidentifikasi lima fitur penting dari tiap cerpen, karakter, latar belakang kejadian, masalah, usaha yang dilakukan, dan solusi akhir. Pengajaran mengenai struktur cerita ditemukan telah meningkatkan pemahaman membaca siswa yang berprestasi rendah. Para siswa dalam pembelajaran kooperatif integratif juga membuat penjelasan terhadap prediksi mengenai bagaimana masalah-masalah akan di atasi dan merangkum unsur-unsur dari cerita kepada satu sama lain (Slavin 2008:203).

\section{Pengertian Kemandirian}

Kemandirian merupakan salah satu aspek kepribadian yang sangat penting bagi individu. Seseorang dalam menjalani kehidupan ini tidak pernah lepas dari cobaan dan tantangan. Individu yang memiliki kemandirian tinggi relatif mampu menghadapi segala permasalahan karena individu yang mandiri tidak tergantungpada orang lain, selalu berusaha menghadapi dan memecahkan masalah yang ada.

Menurut Antonius (2000:145) seseorang yang mandiri adalah suatu suasana dimana seseorang mau dan mampu mewujudkan kehendak atau keinginan dirinya yang terlihat dalam tindakan atau perbuatan nyata guna menghasilkan sesuatu (barang atau jasa) demi pemenuhan kebutuhan hidupnya dan sesamanya. Mutadin (2002, www.e_psikologi.com)kemandirian adalah suatu sikap individu yang diperoleh secara kumulatif selama perkembangan, individu akan terus belajar untuk bersikap mandiri dalam menghadapi berbagai situasi lingkungan, sehingga individu pada akhirnya akan mampu berfikir dan bertindak sendiri dengan kemandiriannya seseorang dapat memilih jalan hidupnya untuk dapat berkembang dengan lebih mantap.

\section{KERANGKA BERPIKIR}

Model pembelajaran merupakan salah satu cara yang diduga tepat untuk mengoptimalkan keefektifan belajar. Pemilihan model yang tepat sangat berpengaruh terhadap perolehan hasil belajar, khususnya dalam pembelajaran menulis cerpen.

Tabel 2.3 Keunggulan Model Pengajaran Tidak Langsung dan Model Kooperatif Integratif

\begin{tabular}{|cc|c|}
\hline $\begin{array}{c}\text { Keunggulan model pengajaran tidak langsung } \\
\text { (nondirective teaching) }\end{array}$ & $\begin{array}{c}\text { Keunggulan model pembelajaran kooperatif } \\
\text { integratif }\end{array}$ \\
\hline 1. $\begin{array}{l}\text { Model pengajaran ini digunakan untuk } \\
\text { menjaga pusat perkembangan diri siswa }\end{array}$ & $\begin{array}{c}\text { 1. Pembelajaran kooperatif integratif diduga } \\
\text { sangat tepat untuk meningkatkan }\end{array}$ \\
\hline
\end{tabular}


dan membantu siswa mengatasi masalahmasalah pembelajaran.

2. Model ini menciptakan sebuah lingkungan yang memudahkan siswa dan guru bekerja sama dalam proses pembelajaran.

3. Model ini memudahkan siswa untuk saling berbagi gagasan secara terbuka dan membangun komunikasi yang sehat. keterampilan siswa dalam menulis.

2. Dominasi guru dalam pembelajaran berkurang.

3. siswa termotivasi pada hasil secara teliti, karena bekerja dalam kelompok.

4. siswa dapat memahami makna soal dan saling mengecek pekerjaannya.

5. membantu siswa yang lemah.

6. meningkatkan hasil belajar siswa.

Selain model pembelajaran yang digunakan oleh guru, kemandirian siswa dalam proses belajar juga memiliki peranan yang sangat penting. Belajar mandiri bukanlah berarti belajar secara sendiri melainkan belajar yang bertumpu pada kegiatan dan tanggung jawab siswa itu sendiri untuk mencapai keberhasilan belajarnya. Kemampuan siswa menulis cerpen berhubungan dengan kemandirian siswa, dengan penelitian ini akan diketahui apakah siswa yang memiliki taraf kemandirian tertentu dalam arti memiliki keterampilan menulis cerpen menurut ukuran yang dikembangkan dalam penelitian ini. Besarnya perbedaan prestasi keterampilan menulis cerpen yang tingkat tinggi dan rendah berhubungan dengan besarnya taraf kemandirian siswa.

Kelas eksperimen 1 dikenai model kooperatif integratif dilihat dari tingkat kemandirian siswa dan kelas eksperimen 2 dikenai model pengajaran tidak langsung dilihat dari tingkat kemandirian siswa. Kedua model tersebut diterapkan dalam tes pembelajaran menulis cerpen berdasarkan tingkat kemandirian siswa, sehingga akan terlihat tingkat kemandirian siswa dan hasil belajar menulis cerita pendek berdasarkan model yang sudah diterapkan dan diharapkan menghasilkan pembelajaran efektif. Dalam pembelajaran menulis cerita pendek yang dibelajarkan dengan model pengajaran tidak langsung dan model kooperatif integratif diharapkan dapat ditemukan model pembelajaran yang lebih cocok dalam pembelajaran menulis cerpen.

\section{HIPOTESIS}

Berdasarkan kerangka berpikir yang telah dipaparkan, dan sehubungan dengan permasalahan yang telah dilakukan, diperoleh sejumlah hipotesis sebagai berikut.

a. Model pengajaran tidak langsung diduga lebih cocok dibandingkan dengan model pembelajaran kooperatif integratif kemampuan menulis cerpen dilihat dari siswa yang memiliki tingkat kemandirian tinggi.

b. Model kooperatif integratif diduga lebih cocok dibandingkan dengan model pengajaran tidak langsung kemampuan menulis cerpen dilihat dari siswa yang memiliki tingkat kemandirian rendah.

c. Diduga ada interaksi antara model pengajaran tidak langsung dan model kooperatif integratif.

\section{METODE PENELITIAN}

\section{Desain Penelitian}

Penelitian ini termasuk jenis eksperimen quasi.Desain yang digunakan dalam penelitian ini adalah desain faktorial sederhana dua kali atau $2 \times 2$.Dalam desain ini dua 
variabel bebas utama dimanipulasi secara bersamaan dengan memperhitungkan variabel atribut untuk dilihat efek masing-masing variabel bebas utama (baik secara terpisah maupun bersama-sama), efek variabel atributnya, dan interaksi variabel bebas dengan variabel atribut pada variabel terikat.Dalam hal ini variabel atribut lebih berfungsi sebagai control.Dua variabel bebas yang sama-sama dimanipulasi adalah model kooperatif integratif dan model pengajaran tidak langsung.Variabel atributnya adalah tingkat kemandirian siswa, yaitu kemandirian tinggi dan kemandirian rendah. Efek variabel bebas akan dilihat pada variabel terikat dalam hal prestasi belajar.

\section{Variabel Penelitian}

Variabel adalah objek penelitian, atau apa yang menjadi titik perhatian suatu penelitian (Arikunto 2006:118). Variabel dalam penelitian ini adalah

\section{a. Variabel Bebas}

Variabel bebas penelitian ini adalah model pengajaran tidak langsung, model kooperatif integratif dan tingkat kemandirian siswa (kemandirian tingkat tinggi dan kemandirian tingkat rendah).

\section{b. Variabel Terikat}

Variabel terikat penelitian ini adalah kemampuan menulis cerpen siswa.

\section{Data Penelitian}

Data yang hendak dikumpulkan dalam penelitian ini adalah sebagai berikut.

(1) Data yang berupa keterampilan menulis cerpen sebelum dan setelah diberi perlakuan. Hasil tes kemampuan dimaksudkan untuk mengetahui tingkat perbedaan dan keefektifaan model pengajaran tidak langsung dan model kooperatif integratif dilihat dari tingkat kemandirian siswa. Data hasil belajar yang telah didapat dari tiap kelas dibandingkan.

(2) Data yang berupa skala kemandirian.

\section{Instrumen Penelitian}

Dalam penelitian ini sebagai instrumen penelitiannya adalah tes kemandirian dan tes menulis cerpen. Instrumen penelitian tes kemandirian ini digunakan untuk mengetahui kemandirian siswa yaitu siswa yang tingkat kemandiriannya tinggi dan siswa yang tingkat kemandiriannya rendah.

\section{Teknik Pengumpulan Data}

Metode pengumpulan data penelitian ini adalah (a) tes kemampuan menulis cerpen, dan wawancara.

\section{a. Teknik Tes}

Tes adalah serentetan pertanyaan atau latihan serta alat lain yang digunakan untuk mengukur keterampilan, pengetahuan intelegensi, kemampuan atau bakat yang dimiliki oleh individu atau kelompok (Arikunto 2006: 150). Instrumen tes dalam penelitian ini meliputi tes kemampuan menulis cerpen.

\section{b. Teknik Wawancara}

Teknik wawancara digunakan untuk memperoleh data secara langsung mengenai berbagai hal yang berkaitan dengan keterampilan menulis cerpen melalui penerapan model pengajaran 
tidak langsung dan model kooperatif integratif. Data yang diambil mengenai kesan dan pesan dari pendapat siswa terhadap pembelajaran yang telah diberikan.

\section{LANGKAH-LANGKAH PENGUJIAN HIPOTESIS}

Hipotesis-hipotesis nol yang akan diuji dalam penelitian ini adalah sebagai berikut.

1. Kemampuan siswa menulis cerpen yang memiliki tingkat kemandirian tinggi dengan perlakuan model pengajaran tidak langsung tidak lebih besar atau sama saja dengan kemampuan menulis cerpen siswa yang memiliki tingkat kemandirian tinggi model kooperatif integratif.

Ho $\quad: \quad \mu$ KTMTL $\leq \mu$ KTMKI

$\mathrm{Ha}: \quad \mu \mathrm{KTMTL}>\mu \mathrm{KTMKI}$

dengan:

$\mu$ KTMTL : nilai rata-rata pascates kemampuan menulis cerpen siswa yang memiliki tingkat kemandirian tinggi model pengajaran tidak langsung.

$\mu$ KTMKI : nilai rata-rata pascates kemampuan menulis cerpen siswa yang memiliki tingkat kemandirian tinggi model kooperatif integratif.

2. Kemampuan siswa menulis cerpen yang memiliki tingkat kemandirian rendah dengan model kooperatif integratif tidak lebih besar atau sama saja dengan kemampuan siswa menulis cerpen yang memiliki tingkat kemandirian rendah dengan model pengajaran tidak langsung.

$\begin{array}{llll}\mathrm{Ho} & : & \mu \mathrm{KRMKI} \leq & \mu \mathrm{KRMTL} \\ \mathrm{Ha} & : & \mu \mathrm{KRMKI}> & \mu \mathrm{KRMTL}\end{array}$

dengan:

$\mu$ KRMKI : nilai rata-rata pascates kemampuan menulis cerpen siswa yang memiliki tingkat kemandirian rendah model kooperatif integratif.

$\mu$ KRMTL : nilai rata-rata pascates kemampuan siswa menulis cerpen yang memiliki tingkat kemandirian rendah model pengajaran tidak langsung.

3. Tidak ada interaksi antara kemampuan menulis cerpen model pengajaran tidak langsung dengan model kooperatif integratif.

Ho : KMTL X KMKI $\leq 0$

$\mathrm{Ha}: \mathrm{KMTL} X \mathrm{KMKI}>0$

\section{HASIL PENELITIAN DAN PEMBAHASAN \\ Pembahasan}

Pengetesan tingkat kemandirian dilakukan oleh Psikolog, bernama Trubus Raharjo, Msi. Psikolog, peneliti, dan dibantu oleh Guru bahasa Indonesia SMA 2 Semarang. Tujuan pengetesan yaitu untuk memenuhi tuntutan penelitian, yaitu pengelompokan subjek penelitian menjadi kelompok yang memiliki tingkat kemandirian tinggi dan kelompok yang memiliki tingkat kemandirian rendah.

Pengukuran dikenakan kepada subjek penelitian, yaitu siswa kelas X SMA Negeri 2 Semarang. Berdasarkan hasil pengukuran, diperoleh dua kelompok subjek penelitian, yaitu (1) kelompok 1 terdiri dari 30 siswa, yaitu 15 memiliki tingkat kemandirian tinggi dan 15 siswa memiliki tingkat kemandirian rendah diterapkan sebagai kelompok eksperimen 1 diperlakukan dengan model kooperatif integratif. Hasil cerpen siswa kemudian dianalisis berdasarkan tingkat kemandirian siswa, dan dari hasil tersebut dapat diketahui nilai cerpen siswa dilihat dari tingkat kemandirian siswa dan model kooperatif integratif yang diperlakukan dalam pembeljaran menulis cerpen. 
Kelas eksperimen 2 diperlakukan dengan model pengajaran tidak langsung, dilakukan di kelas X-3 terdiri atas 30 siswa, yaitu 15 siswa yang memiliki tingkat kemandirian tinggi dan 15 siswa memiliki tingkat kemandirian rendah ditetapkan sebagai kelompok eksperimen 2 . Hasil cerpen siswa kemudian dianalisis berdasarkan tingkat kemandirian siswa, dan dari hasil tersebut dapat diketahui nilai cerpen siswa dilihat dari tingkat kemandirian siswa dan model pengajaran tidak langsung yang diperlakukan dalam pembeljaran menulis cerpen.

Penerapan model pengajaran tidak langsung dan model kooperatif integratif terhadap siswa yang memiliki tingkat kemandirian tinggi, menunjukkan adanya perbedaan terhadap keterampilan menulis cerpen. Dari hasil penelitian diperoleh nilai rata-rata siswa yang mendapat model pengajaran tidak langsung adalah 80, sedangkan nilai rata-rata siswa yang mendapat pengajaran model kooperatif integratif adalah 78 , dan F hitung $(37,008)>\mathrm{F}$ tabel $(7,08)$. Dengan demikian kemampuan menulis cerpen siswa yang tingkat kemandirian tinggi dan diajarkan melalui model pengajaran tidak langsung lebih cocok dibandingkan dengan siswa yang memiliki tingkat kemandirian tinggi dengan perlakuan model kooperatif integratif.

Penerapan model pengajaran tidak langsung dan model kooperatif integratif terhadap siswa yang memiliki tingkat kemandirian rendah, menunjukkan adanya perbedaan terhadap keterampilan menulis cerpen. Dari hasil penelitian diperoleh nilai rata-rata siswa yang mendapat model pengajaran tidak langsung adalah 73, sedangkan nilai rata-rata siswa yang mendapat pengajaran kooperatif integratif adalah 78 , dan $\mathrm{F}$ hitung $(59,031)>\mathrm{F}$ tabel $(7,08)$. Dengan demikian kemampuan menulis cerpen siswa yang tingkat kemandirian rendah dan diajarkan melalui model kooperatif integratif lebih cocok dibandingkan dengan siswa yang memiliki tingkat kemandirian rendah dengan perlakuan model pengajaran tidak langsung.

Adanya interaksi antara pengajaran tidak langsung dengan model kooperatif integratif. Hal ini menunjukkan bahwa kedua model pengajaran yang diterapkan pada siswa ada hubungan yang berarti terhadap kemampuan menulis cerpen. Hal tersebut ditunjukan dengan hasil Fhitung 5,751> 4,0.

Adapun hasil pengujian hipotesis dapat dilihat pada ilustrasi pengujian hipotesis dan interaksi sebagai berikut.

Grafik 4.2

Ilustrasi Pengujian Hipotesis dan Interaksi

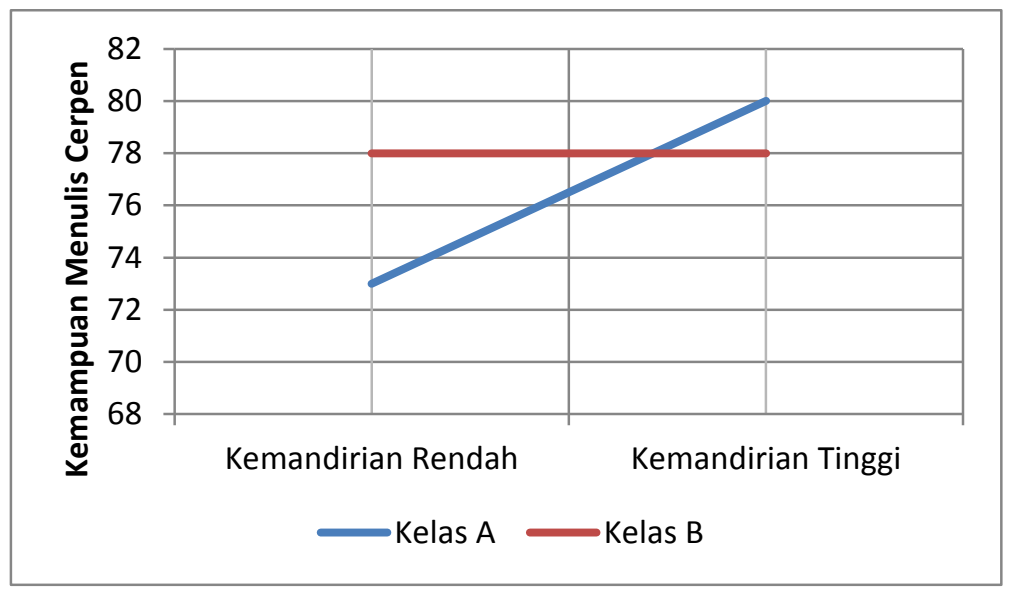


Kemampuan menulis cerpen siswa kelas A dengan kemandirian rendah dan mendapat pengajaran tidak langsung lebih rendah dibandingkan siswa kelas B yang mendapatkan pengajaran model kooperatif integratif.

Kemampuan menulis cerpen siswa kelas A dengan kemandirian tinggi dan mendapat pengajaran tidak langsung lebih tinggi dibandingkan siswa kelas B yang mendapatkan pengajaran model kooperatif integratif. Ada interaksi antara pengajaran tidak langsung dengan model kooperatif integratif.

Dengan demikian dapat disimpulkan bahwa penerapan pengajaran tidak langsung dan model kooperatif integratif pada kelompok eksperimen terhadap kemampuan menulis cerpen sangat berarti baik bagi kelompok yang memiliki kemandirian tinggi maupun bagi yang memiliki kemandirian rendah.

\section{PENUTUP}

Simpulan

Berdasarkan deskripsi dan uji hipotesis yang telah dikemukakan, terdapat simpulan sebagai berikut.

1. Model pengajaran tidak langsungcocok untuk pembelajaran kemampuan menulis cerpen dilihat bagi siswa yang memiliki tingkat kemandirian tinggi denganF hitung $(37,008)>$ F tabel $(7,08)$.

2. Model kooperatif integratif cocok untuk pembelajaran kemampuan menulis cerpen dilihat bagi siswa yang memiliki tingkat kemandirian rendah $\mathrm{F}$ hitung $(59,031>\mathrm{F}$ tabel $(7,08)$ dan ada interaksi antara model pengajaran tidak langsung dan model kooperatif integratif $\mathrm{F}$ hitung 5,751 > 4,0.

\section{Saran} berikut.

Berdasarkan hasil simpulan penelitian di atas, peneliti menyumbangkan saran sebagai

1. Guru dalam melakukan pembelajaran harus memperhatikan kondisi atau karakteristik siswa, khususnya menulis cerpen. Guru dapat menggunakan model pengajaran tidak langsung untuk siswa yang memiliki kemandirian tinggi karena model ini memudahkan siswa untuk saling berbagi gagasan secara terbuka dan membangun komunikasi yang sehat. Model ini dapat menciptakan sebuah lingkungan yang memudahkan siswa dan guru bekerjasama dalam proses pembelajaran, khususnya kemampuan menulis cerpen.

2. Guru dalam melakukan pembelajaran harus memperhatikan kondisi atau karakteristik siswa, khususnya menulis cerpen. Guru dapat menggunakan model kooperatif integratif untuk siswa yang memiliki kemandirian rendah karena model ini merupakan salah satu model pembelajaran inovatif yang dapat memotivasi siswa karena bekerja dalam kelompok sehingga dapat meningkatkan hasil belajar siswa dan dapat membantu siswa yang lemah dalam kemampuan menulis cerpen.

\section{DAFTAR PUSTAKA}

Ali, Mohammad dan Mohammad Asrori.2009. Psikolog Remaja Perkembangan Peserta Didik. Jakarta: Bumi Aksara.

Arikunto, Suhasimi. 2006. Prosedur Penelitian Suatu Pendekatan Praktik. Jakarta: Rineka Cipta. 
Astuti, Retno Dwi. 2005. "Pengaruh Pola Orangtua Terhadap Kemandirian Siswa Dalam Belajar Pada Siswa Kelas XI SMA Negeri Sumpiuh Kabupaten Banyumas". Tesis. Semarang. Program Pascasarjana Unnes.

Azwar, Syaifudin.2007. Penyusunan Skala Psikologi.Yogyakarta: Pustaka Belajar.

Baharuddin. 2007. Teori Belajar dan Pembelajaran. Yogyakarta: Ar Ruzzmedia.

Joyce, B., Marsha, W., dan Emily, C. 2009. Models Of Theaching. Yogyakarta: Pustaka Pelajar.

Dahar, W.R. 1989. Teori-Teori Balajar.Jakarta: Erlangga.

Dimyati dan Mudjiono. 2002. Belajar dan Pembelajaran. Jakarta: PT Rineka Cipta.

Edi Sutopo. 2010. "Peningkatan Keterampilan Menulis Cerpen Berdasarkan Pengalaman Melalui Model Diskusi Kreatif dengan Media Blog pada Siswa Kelas IX A MTs Negeri Jeketro Kabupaten Grobogan”. Tesis. Semarang: Program Pascasarjana Unnes.

Endraswara, Suwandi. 2003. Membaca, Menulis, Mengerjakan Sastra. Yogyakarta: Rembang.

Erkaya, Odelia Rocha. 2006. Benefit of Using Short Stories in The EFL Contect. www.asianefl_journal.com/pta_nov ore.pdf(diunduh 23 Agustus 2011).

Eysenk, H. 2002. Creativity and Personality: A Theoretical Perspective, Psychological Inquiry. Journal: Vo.10. www.cpsb.com/creative/Theoretical-PerspectivesCreative_Learning_Facilitation.pdf.(diunduh 15 Agustus 2011).

Fatimah, E. 2006.Psikologi Perkembangan (Perkembangan Peserta Didik). Bandung: Pustaka Setia.

Feist, J dan Fiest, G.J. 2008. Theories of Personality. Yogyakarta: Pustaka Belajar.

Gie, The Liang. 2002. Terampil Mengarang. Yogjakarta: Andy

Hamalik, Oemar. 2009. Proses Belajar Mengajar. Jakarta: Bumi Aksara

Harjono, S. 1998. Prinsip-Prinsip Pengajaran Bahasa dan Sastra. Jakarta: Depdikbud.

Isjoni. 2009. Pembelajaran Kooperatif. Yogyakarta: Pustaka Pelajar.

Kartawijaya, Anne dan Kay Kuswanto. 2004. Artkel Tentang “ Mendidik Anak untuk Mandiri”. http://www.geogle.com.e_psikologi(diunduh 12 Februari 2011).

Keraf, Goys. 2007. Eksposisi Komposisi lanjut II. Jakarta: Gramedia Widiasarana. 
Kezwer, Paula. 1987. The Extroved Vs. the Introved Personality and Second Language Learning. Journal: Canada Vol.5. www.teslcanadajournal.ca/index.php/tesl/article/. (diunduh 22 Januari 2011).

Khumaedah. 2006. "Hubungan Kebiasaan Menulis Buku Harian Dengan Kemampuan Menulis Cerpen dan Mengapresiasi Karya Satra Siswa SMA di Kabupaten Jepara”. Tesis. Semarang: Program Pascasarjana Unnes.

Kurniawan, Khaerudin. 2008. Model Pengajaran Menulis Bahasa Inonesia. Yogyakarta: UNY.

Lie, Anita. 2008. Cooperative Learning. Jakarta: Gramedia.

Meilon, Beny. 2009. "PengaruhMetode Pembelajaran Kooperatif Tipe TGT (Team Game Tournament) Dalam Pembelajaran Matematika Pokok Bahasan Bangun Ruang Ditinjau Dari Kemandirian Siswa”. Tesis.Semarang: Program Pascasarjana Unnes.

Munandar, U. 1992. Mengembangkan Bakat dan Kreativitas Anak. Jakarta: Gramedia.

Nadeak, Wilson. 1989. Bagaimana Menulis Cerita Pendek. Bandung: Yayasan Kalam Hidup

Nursisto. 1999. Penuntun Mengarang. Yogyakarta: Adi Cipta Karya Nusa.

Nurudin. 2010. Dasar-dasar Penulisan. Malang: UMM Press. http://www.Nurudin's.weblog.htm (diunduh 25 Maret 2011)

Nuryatin, Agus. 2010. Mengabadikan Pengalaman dalam Cerpen. Rembang: Yayasan Adhigama.

Panca Dewi Purwati. 2009. "Pengembangan Media Bangun Multifiksi untuk Peningkatan Kompetensi Menulis Cerita Pendek Siswa SMP". Tesis: Semarang: Program Pascasarjana Unnes.

Rahmanto.1997. Metode Pengajaran Sastra.Yogyakarta: Kanisius.

Silvester, Niko dan Alexander, Rafa. 2004. Panduan Menulis Fiksi untuk Pemula.Jakarta: Platinum.

Suriamiharja, Agus, dkk. 1997. Petunjuk Praktis Menulis. Jakarta: Depdikbud.

Semi, Atar. 1984. Menulis Cerpen. Jakarta: Balai Pustaka.

Slavin, Robert. E. 2009. Cooperative Learning: Teori, Riset dan Praktik. Bandung: Nusa Media

Sudjana. 2002. Metoda Statistika. Bandung: Tarsito.

Sudjiman, Panuti. 1992. Memahami Cerita Rekaan. Jakarta: Aksara baru. 
Sugiyono. 2009. Statistika untuk Penelitian. Bandung: ALFABETA.

Sumardjo, Jakob dan Saini K.M. 1994. Apresiasi Kesusastraan. Jakarta: Gramedia Pustaka Utama.

Syaodih, Nana S.2008. Metode Penelitian Pendidikan. Bandung: ROSDA

Suprijono, Agus. 2009. Cooperative Learning: Teori\& Aplikasi PAIKEM. Yogyakarta: Pustaka Pelajar.

Sutikno.2010."Peningkatan Keterampilan Menulis Karangan Berbagai Topik Sederhana dengan Model Cooperative Reading and Composition (CIRC) yang di Dukung Media Film Tematik pada Siswa SD Kelas VI Sekolah Dasar Negeri Tandang 6 Semarang. Tesis.Semarang: Pascasarjana Unnes.

Suyitno.2005. Komponen-komponen dalam Pembelajaran CIRC.http://Suyitno.wordpress.com/Komponen-komponen-dalam -pembelajaranCIRC-oleh-suyitno. (diunduh 09 April 2010)

Tarigan, H. G. 1984. Menulis sebagai Suatu Keterampilan Bahasa. Bandung: Angkasa.

Tartib. 2010. "Pengembangan Model Sinektik pada Pembelajaran Menulis Cerpen Berkonteks Multikultural dalam Pembentukan Karakter Siswa SMP". Tesis.Semarang: Program Pascasarjana Unnes.

Trianto. 2007. Model-Model Pembelajaran Inovatif Berorientasi Konstruktivistik. Jakarta Pusat: Prestasi Pustaka.

Winatraputra, Udin S. 2001. Model-Model Pembelajaran Inovatif. Jakarta. Jakarta: PAUPPAI, Universitas Terbuka.

Yan, Kui. 2006. An Approach to Teaching Short Stories. http://ccsenet.org/journal/index.php/ijbm/article/view/3246/2947 (diunduh 23 Agustus 2011). 